\title{
Analytical methods for the identification of micro/nano metals in e-cigarette emission samples: a review
}

\author{
Wafaa Waleed AL-Qaysi ${ }^{1,2}$ (D) Fatma H. Abdulla ${ }^{2}$ (D)
}

Received: 5 February 2021 / Accepted: 4 July 2021 / Published online: 18 August 2021

(c) Institute of Chemistry, Slovak Academy of Sciences 2021

\begin{abstract}
In this review, numerous analytical methods to quantify the heavy and trace elements emitted from electronic cigarettes, cigarettes liquid and atomizer. The selection of a method was dependent upon the purpose, e.g., quantification or identification of elements only. The introductory part of this review focuses on describing the importance of setting up an electronic cigarettes- associated safety profile. The review dealt with studies that assessed elements in sizes ranging from nano to micro. The formation of different degradation chemical substances as well as impurity trends can be indicated through chemical investigation of metals in electronic cigarettes. Some studies have been covered that show the uses and benefits of. It is noticeable from all the collected sources that the minerals emitted from the smoke of e- cigs do not constitute any significant damage, as the percentage is very small, with the exception of minerals that may be emitted from the components of the device after heating it if the components of the e- cig are of poor specifications, except in the case of long-term accumulation. For this reason, an electronic cigarette can help smokers to quit smoking tobacco and replace it with electronic cigarettes smoke with distinctive flavors.
\end{abstract}

Keywords Electronic-cigarettes $\cdot$ Atomizer $\cdot$ Heavy metals $\cdot$ Analytical methods $\cdot$ Nanoparticles $\cdot$ And COVID-19

\section{Introduction}

Electronic cigarettes (E-cig) are battery-charged device that mimics the act of smoking by generating the physical sensation, used to vaporize a liquid that may or may not contain nicotine (Susi et al. 2020). E-cigs are submitted to by different names, including "electronic cigarettes," "e-cigarettes," "electronic nicotine delivery systems (ENDS)," "alternative nicotine delivery systems (ANDS)," "electronic vapor products," "e-cigars," “e-pipes," "e-hookahs," "e-shishas," "mods," "personal vaporizers," "vape pens," "vapes", "vapor pens," "hookah pens" and "tank systems" (Pearson et al. 2018). It was invented by Chinese pharmacist Hon Lik

Wafaa Waleed AL-Qaysi

wafa.w@sc.uobaghdad.edu.iq

Fatma H. Abdulla

chemfatma@sc.uobaghdad.edu.iq

1 Institute of Analytical Chemistry, Chemo and Biosensors, University of Regensburg, Universitätsstraße 31, 93040 Regensburg, Germany

2 Department of Chemistry, College of Science, University of Baghdad, Al-Jadriya campus, 10071 Baghdad, Iraq in 2003 (Patent and Link, xxxx). E-cig consists of a heating system, and a fluid container having pump generates aerosols by heating an e-liquid solution with a metal coil (Levy et al. 2018). Atomizers are ionized the analyte by isolated it in the gas phase and evaporates the e-liquid fillers to introduce wet aerosol. An aerosol has been created from atomizer e-cigs called vapor contains of propylene glycol, vegetable glycerin (VG) and/or propylene glycol (PG) with water (Goniewicz et al. 2014) to produce aerosol, glycerine $(\mathrm{G})$, nicotine $(\mathrm{N})$ (in various concentrations) $(0-36 \mathrm{mg} / \mathrm{mL}$ ) (Glasser et al. 2017), chemical constituents for flavoring (F) agents (Dai 2017), which have a sleek design are even more attractive to adolescents (Julia et al. 2019; Goniewicz et al. 2018a; Huang et al. 2019; McKelvey et al. 2018) and other additives to users via an inhaled aerosol.

Three types of e-cigs may be classified: cig-a-like, tank and pod-based e-cigs. E-cigs were designed with components of heavy metals that have already been reported throughout the vapor of aerosol, which poses a hazard to public health of smokers due to various their toxicity (Nicholas et al. 2019). To warm the wick and evaporate the e-liquid, conductive wire filaments $(\mathrm{Ni}-\mathrm{Cr}$ or other elements) are used. These resistive wires are often connected 
to non-resistive (sometimes $\mathrm{Ag}$-coated), $\mathrm{Cu}$ wire extensions, and $\mathrm{Sn}$ the wires are attached to each other by solder joints as well as to the air tube and mouthpiece (Williams et al. 2013). In several previous studies, e-cig users have proven that it helped them reduce or even stop smoking completely and viewed as a healthier alternative to a $\mathrm{CC}_{\mathrm{S}}$ (Berg et al. 2014; Biagio et al. 2013). In recent times, it has been recorded details that e-liquids generate relatively small size (107-165 nm and 165-255 nm) (Manigrasso et al. 2015). It is essentially unsafe for finer particulate materials less than $2.5 \mu \mathrm{m}$ in diameter (Raaschou-Nielsen et al. 2013). Small particle emissions may increase the risk of heart failure, lung cancer and asthma attacks and can interfere with lung development and function (Olmedo et al. 2018). Co-toxicity after 6 months of vaping has been identified as a cause of interstitial giant cell pneumonia (Fels Elliott et al. 2019). Owing to prolonged exposure to Co, the "cobalt lung" is known at work level to be pneumoconiosis. Zervas et al. (2014) found that many nanoparticles are formed by e-cig fluids, up to 3000 times more than found in ambient air. Laugesen (2009) discovered much smaller particles emit from e-cigs. While Ingebrethsen et al. (2012), Zhang et al. (2013), Bertholon et al. (2013), much bigger particles emit from e-cigs than in $\mathrm{CC}_{S}$, and Fuoco et al. (2014) observed that e-cigs and $\mathrm{CC}_{\mathrm{S}}$ emit aerosols with similar particle sizes of fine and ultrafine vapor particles. In addition, heavy metal particles produced by e-cigs are also an important mediator of cellular oxidative stress (Chad et al. 2016). Most firms do not report e-liquid ingredients or offer documentation of protection, sound production processes and/or quality management procedures. (Brown and Cheng 2014). In addition, several tests have measured elevated levels of harmful organic and inorganic chemicals in e-cig liquid (Dunbar et al. 2018a; Kamilari et al. 2018), and aerosols (Levy et al. 2018; Mikheev et al. 2016). The presence of elements, such as $\mathrm{As}, \mathrm{Cr}, \mathrm{Pb}, \mathrm{Ni}$, in aerosols of e-cig is given the extreme health risks, a considerable concern, given their serious health impacts. At varying amounts, e-liquids can also contain As and other elements (Zhao et al. 2019). Zinc was significantly elevated in the e-cig users $(584.5 \pm 826.6 \mu \mathrm{g} / \mathrm{g})$ compared with non-smokers $(413.6 \pm 233.7 \mu \mathrm{g} / \mathrm{g}, p=0.03)$. Linear regression analysis showed a significant correlation between urinary zinc concentration and (8-hydroxy-2'deoxyguanosine) $8-\mathrm{OHdG}$ in the e-cig users. Pisinger et al. (2015) and Sakamaki-Ching et al. (2020) summarize the effects of the defined fluid and vapor content (glycols, nicotine, metals, dust, tobacco-specific nitrosamines). Traces of certain inorganic metals and poisonous elements such as $\mathrm{Na}$, $\mathrm{Br}, \mathrm{Au}, \mathrm{Sc}, \mathrm{Fe}$ and $\mathrm{Co}$ can be found in e-liquids. Long-term experiments are important to determine whether these elements are able to accumulate in the lung and cause harmful effects over exposure for a long time (Pasquale et al. 2019). In addition, heating coils are made of nichrome (a blend of
$\mathrm{Ni}$ and $\mathrm{Cr}$ ) and stainless steel in e-cigs. Toxic elements may be leached into vapor aerosols from heated coils (Margham et al. 2016). This is why $\mathrm{Ni}$ and $\mathrm{Cr}$ are found in e-cig aerosols, but not in e-liquids (Papaefstathiou et al. 2019; Gray et al. 2019). Although tests have shown observable element concentrations in e-liquids and aerosols, such as $\mathrm{Al}, \mathrm{Cr}, \mathrm{Fe}$, $\mathrm{Pb}, \mathrm{Mn}, \mathrm{Ni}$ and $\mathrm{Sn}$, the related vaporization hazard to health posed by these elements is not established in long-term studies (Dominic et al. 2017). The e-contribution cigs to the reflectivity of elements are not well known, particularly due to the rapidly evolving nature of devices and e-liquids (Williams et al. 2019a,b; Williams and Talbot 2019).

The objective of this review is aimed at focusing the role of various analytical techniques such as inductively coupled plasma-mass spectrometry (ICP-MS), inductively coupled plasma-optical emission spectrometry (ICP-OES), flame atomic absorption Spectroscopy (FAAS), and X-Ray Fluorescence spectroscopy (XRFS) for estimating the elements emitted from e-cigs and e-liquid, but it did not cover all available technologies that may be used in the future. As well the relationship between electronic cigarette vaping and infection with the coronavirus was also highlighted.

\section{Analytical methods for determination of trace and heavy metals in E-cig}

\section{Inductively coupled plasma-mass spectrometry (ICP-MS)}

ICP-MS is a technique for detect multi-elements with low concentrations of metals $(\mu \mathrm{g} / \mathrm{L}-\mathrm{ng} / \mathrm{L})$. In the first chemical composition test of e-cig cartridge fluids and aerosols developed in 2005 by Brown and Milton (2005), low concentrations of as much as $2-4 \mathrm{ng} / \mathrm{L}$ have been calculated for all e-liquid elements. In 2013, Goniewicz et al. (2014), 12 metals quantify analyzed such as $\mathrm{Co}, \mathrm{Ni}, \mathrm{Cu}, \mathrm{Zn}, \mathrm{Cd}, \mathrm{Pb}, \mathrm{As}, \mathrm{Cr}$, $\mathrm{Se}, \mathrm{Mn}, \mathrm{Ba}, \mathrm{Rb}, \mathrm{Sr}, \mathrm{Ag}, \mathrm{Tl}$ and $\mathrm{V}$. Showed that $\mathrm{Cd}, \mathrm{Ni}$ and $\mathrm{Pb}$ were present in all e-cig vapors excluding $\mathrm{Cd}$ not detected in the product. The concentration of $\mathrm{Cd}=0.01-0.22 \mu \mathrm{g}$, $\mathrm{Ni}=0.11-0.29 \mu \mathrm{g}$, and $\mathrm{Pb}=0.03-0.57 \mu \mathrm{g}$ per 150 puffs of e-cig. In Ruyan report (Laugesen 2008), nine metal cartridges have been tested for $\mathrm{As}, \mathrm{Sb}, \mathrm{Cd}, \mathrm{Cr}, \mathrm{Co}, \mathrm{Cu}, \mathrm{Pb}, \mathrm{Mn}$ and Ni presence. The limited of detection (LOD) values for Cd below $0.01 \mu \mathrm{g} /$ cartridge, As and $\mathrm{Pb}$ below $0.1 \mu \mathrm{g} / \mathrm{car}-$ tridge, while $\mathrm{Cr}$ and $\mathrm{Ni}$ below $0.2 \mu \mathrm{g} /$ cartridge. In a study by Ashraf et al., 22 cartomizers from a leading producer were analyzed (Ashraf 2011), he studied the concentration of $\mathrm{Cd}$, and $\mathrm{Pb}$ in Saudi Arabia, and various cig brands are sold and/or made. He estimated the average levels of $\mathrm{Cd}=1.81 \mu \mathrm{g} / \mathrm{g}$, and $\mathrm{Pb}=2.46 \mu \mathrm{g} / \mathrm{g}$ dry weight from smoking 20 cigs of one pack. Applied to vaping of e-cig samples. Cheng et al. (2014) have reported wide ranges in the levels 
of elements in 2014. Digested seven metals samples for $\mathrm{Cr}$, $\mathrm{Mn}, \mathrm{Co}, \mathrm{Ni}, \mathrm{As}, \mathrm{Cd}$ and $\mathrm{Pb}$ are studied by (Steven et al. 2014), expressed as ng/regimen cigs smoked per sprint. In several e-liquid's, e-vapor samples, five metals quantifiable amounts of $\mathrm{Al}, \mathrm{Co}, \mathrm{Mn}, \mathrm{Ni}$ and $\mathrm{Pb}$ were appeared by Saffari et al. (2014), in e-vapors, $\mathrm{Be}, \mathrm{Cu}, \mathrm{Hg}, \mathrm{V}$ and $\mathrm{Zn}$ were not quantified in any collected solution. In certain e-vapors, up to 0.14 for $\mathrm{Cd}, 3.4$ for $\mathrm{Cr}$, and 0.47 for $\mathrm{Sb} \mathrm{pg} / \mathrm{mL}$ of puff. In the Kentucky 3R4F standard reference cigarettes, four metals quantified from $1.02 \mathrm{pg} / \mathrm{mL}$ puff for Tl to $44.98 \mathrm{pg} /$ $\mathrm{mL}$ puff for Cd. Schober et al. (2014) analyzed the smoke of e-cig and 11 trace elements quantifiable amounts $\mathrm{Al}, \mathrm{Cd}$, $\mathrm{Cr}, \mathrm{Cu}, \mathrm{Fe}, \mathrm{Mn}, \mathrm{Mg}, \mathrm{Ni}, \mathrm{Ti}, \mathrm{V}$ and $\mathrm{Zn}$, to be between 0.3 and $667 \mathrm{ng} \mathrm{m}^{-3}$. In 2015, Fernández et al. (María et al. 2015), a new approach for determining trace quantities of $\mathrm{Pb}^{2+}$ based on rhodamine B dye fluorescent signal enhancement in e-cigs refill alternatives. Showed high sensitivity, sufficient selectivity and good foreign ion tolerance, validated with satisfactory performance. He found the $\mathrm{LOL}=7.4 \times 10^{-4}-3.4$ $\mathrm{mg} \mathrm{L}^{-1}, \mathrm{LOD}=2.2 \times 10^{-4} \mu \mathrm{g} \mathrm{L}^{-1}, \mathrm{LOQ}=7.4 \times 10^{-4} \mathrm{mg} \mathrm{L}^{-1}$. In 2016 Garat et al. (Beauval et al. 2016), he analyzed 48 trace elements e-liquids from French NHOSS ${ }^{\circledR}$ brand. Five metals were determined such as $\mathrm{Cd}, \mathrm{Cr}, \mathrm{Pb}, \mathrm{Mn}$ and $\mathrm{Ni}$ were detected in all liquids analyzed by (Hess et al. 2017). He analyzed 10 cartomizer liquid, five metals were found in the e-liquids analyzed. They observed considerable variations in the concentration of $\mathrm{Ni}$ and $\mathrm{Cr}$ inside and between brands, which could come from heating elements. While Sandeep et al. (Vinit et al. 2017), referred to the previous researchers (Zhang et al. 2013; Bertholon et al. 2013; Chad et al. 2016; Bansal and Kim 2016). Garat et al. (Nicolas et al. 2017) studied and quantified 15 trace metals in a propylene glycol and glycerol blend in 2017 and subjected them to strong matrix effects in e-liquids. He found the LOD for $\mathrm{Al}=4, \mathrm{As}=1, \mathrm{Be}=0.1, \mathrm{Cd}=0.4, \mathrm{Cr}=3.7, \mathrm{Co}=0.1$, $\mathrm{Cu}=20, \mathrm{~Pb}=1, \mathrm{Mn}=1.6, \mathrm{Hg}=4, \mathrm{Ni}=16, \mathrm{Sb}=0.1, \mathrm{Ti}=0.1$, $\mathrm{V}=0.4 \mathrm{ng} / \mathrm{L}$, except for $\mathrm{Zn}=200 \mathrm{ng} / \mathrm{L}$ related to the studies submitted by Saffari et al. (2014), Ohashi et al. (Shintaro 2018) developed and validated methods for the simultaneous determination 13 components $\mathrm{Al}, \mathrm{As}, \mathrm{Ag}, \mathrm{Be}, \mathrm{Cd}, \mathrm{Cr}$, $\mathrm{Co}, \mathrm{Cu}, \mathrm{Fe}, \mathrm{Ni}, \mathrm{Se}, \mathrm{Sn}$ and $\mathrm{Pb}$ in 2018. In addition, glycerol or 1,2-propylene glycol solutions have been used to study the matrix effects of large aerosol constituents. In Malaysia 2019, Chuo et al. (2019) analyzed heavy elements of interest HMOI in vapor. Used two types of aerosols emitted from e-cigs and 50 various brands of e-liquids. $\mathrm{He}$ used $\mathrm{Cd}, \mathrm{Ni}$, $\mathrm{Pb}$ and $\mathrm{Cr}$ metals. The results showed $\mathrm{Cr}$ was the highest median levels, current $6.86 \mathrm{ng} / \mathrm{m}^{3}$, followed by $\mathrm{Ni}=0.30 \mathrm{ng} /$ $\mathrm{m}^{3}, \mathrm{~Pb}=0.19 \mathrm{ng} / \mathrm{m}^{3}$ and $\mathrm{Cd}=0.01 \mathrm{ng} / \mathrm{m}^{3}$. In the same year, Olmedo et al. (2018) studied the conversion of metals for $\mathrm{Al}=16.3$ and 31.2 versus 10.9 ; for $\mathrm{Cr}=8.38$ and 55.4 versus 0.5 ; for $\mathrm{Ni}=68.4$ and 233 versus 2.03 ; for $\mathrm{Pb}=14.8$ and 40.2 versus 0.476 ; and for $\mathrm{Zn}=515$ and 426 vs. 13 .1. In most samples, $\mathrm{Mn}, \mathrm{Fe}, \mathrm{Cu}, \mathrm{Sb}$ and $\mathrm{Sn}$ were detectable. In 0.0 percent of dispenser, 30.4 percent of aerosol, and 55.1 percent of tank samples, Cd was found in 10.7 percent of dispenser samples, arsenic was found median $26.7 \mu \mathrm{g} /$ $\mathrm{kg}$, and these concentrations were identical in aerosol and tank samples. In 2019, Pappas et al. (Naudia et al. 2019), a method for quantification of seven toxic metals like: $\mathrm{Cr}, \mathrm{Ni}$, $\mathrm{Cu}, \mathrm{Zn}, \mathrm{Cd}, \mathrm{Sn}$ and $\mathrm{Pb}$ in e-cig liquids using triple quadrupole ICP-MS was developed. The LODs for $\mathrm{Cr}=0.031$, $\mathrm{Ni}=0.032, \mathrm{Cu}=3.15, \mathrm{Zn}=1.27, \mathrm{Cd}=0.108, \mathrm{Sn}=0.099$ and $\mathrm{Pb}=0.066 \mu \mathrm{g} / \mathrm{g}$. (Mark et al. 2019), determination 39 elements such as $\mathrm{Ag}, \mathrm{Al}, \mathrm{As}, \mathrm{B}, \mathrm{Ba}, \mathrm{Be}, \mathrm{Cd}, \mathrm{Ce}, \mathrm{Co}, \mathrm{Cr}$, Cs, $\mathrm{Cu}, \mathrm{Dy}, \mathrm{Er}, \mathrm{Eu}, \mathrm{Fe}, \mathrm{Ga}, \mathrm{Gd}, \mathrm{Hg}, \mathrm{Ho}, \mathrm{La}, \mathrm{Lu}, \mathrm{Mn}, \mathrm{Nd}, \mathrm{Ni}$, $\mathrm{Pb}, \mathrm{Pr}, \mathrm{Rb}, \mathrm{Se}, \mathrm{Sm}, \mathrm{Sr}$, Th, Ti, Tl, Tm, U, V, Yb and Zn. In kinetic energy discrimination (KED) mode, all samples were performed, using helium of elevated purity 99.999 percent as the gas collision. (Mary et al. 2019) established a clear, high metal purity, fluoropolymer trap. In conjunction with a fluoropolymer condensation trap, aerosol was produced and collected from select ENDS devices for $\mathrm{Cr}, \mathrm{Ni}, \mathrm{Cu}, \mathrm{Zn}, \mathrm{Cd}$, $\mathrm{Sn}$ and triple quadrupole ICP-MS analysis using a typical machine regimen for puffing. Showed that the concentrations of metals varied from below the LOD to $614 \mathrm{ng} \mathrm{Cu}$ and $339 \mathrm{ng} \mathrm{Zn}$ per 10 puffs for aerosols produced under a set puffing regimen 50 puffs/collection. For all instruments tested, Cd concentrations were below LOD. System-specific $\mathrm{Sn}$ and $\mathrm{Pb}$ aerosol levels varied from below LOD to medium levels of ng. Using a typical smoking regimen, $\mathrm{Cr}$ and $\mathrm{Ni}$ were carried in aerosols at amounts equal to or significantly higher than CCs. Compared to smoke of mainstream cigs, the usually lower amounts of particular elements, $\mathrm{Cd}$ and $\mathrm{Pb}$, carried in ENDS aerosols represent potential reductions in risk to smokers that replace the use of ENDS as cessation devices instead of CCs. Finally, a new systematic review was published in 2020 by Di Zhao et al. (Di et al. 2020) referred to the previous researchers (Goniewicz et al. 2014; Ingebrethsen et al. 2012; Dominic et al. 2017; Schober et al. 2014; Tayyarah and Long 2014; Flora et al. 2016; Beauval et al. 2017; Palazzolo et al. 2017; Song et al. 2018; Zhao et al. 2018).

\section{Inductively coupled plasma-optical emission spectrometry (ICP-OES)}

ICP-OES is a technique for detect multi-elements in a variety of different sample matrices by with usage of plasma and a vacuum-condition spectrometer (Charles and Kenneth 2004). In 2015 by Williams et al. (Monique et al. 2015) determined the initial composition of the concentrations of $\mathrm{Sn}, \mathrm{Cu}, \mathrm{Zn}, \mathrm{Ag}$, Ni and $\mathrm{Cr}$ metals in aerosols of four various brands of e-cig and atomizer. Kim et al. (2018) (Jeffrey et al. 2017) analyzed and quantify the amounts of eight aerosol elements produced from the e-liquid reference 
material (RM). Eight element amounts were observed to be smaller than LOD $1 \mathrm{ppb}$ when a new e-cig was used, while $\mathrm{Pb}=0.097 \pm 0.003 \mathrm{mg} / \mathrm{L}$ and $\mathrm{Mn}=0.001 \pm 0.000 \mathrm{mg} / \mathrm{L}$ were observed in aerosol after 4 months of study 20 -h of cumulative use, suggesting that the metals came from e-cig and not from e-liquid. Thirty-six inorganic chemical elements and their concentrations in e-cig/e-hookah aerosols were detected and determined by Williams et al. (2017), it appears that the elements originated from filament $\mathrm{Ni}, \mathrm{Cr}$, thick-wire Ag-coated $\mathrm{Cu}$, brass clamp $\mathrm{Cu}, \mathrm{Zn}$, solder joints $\mathrm{Sn}, \mathrm{Pb}$, and wick and sheath $\mathrm{Si}, \mathrm{O}_{2}, \mathrm{Ca}, \mathrm{Mg}, \mathrm{Al}$. In two brands of solder and aerosol are available in the e-hs, $\mathrm{Pb}$ was detected up to $0.165 \mu \mathrm{g} / 10$ puffs. In 2018, France Langevin et al. (Bertrand and Maud 2018) determined five metal concentrations such as $\mathrm{As}, \mathrm{Cd}, \mathrm{Hg}, \mathrm{Pb}$ and $\mathrm{Sb}$ in two e-liquid products at the concentration levels specified in The French National Organization for Standardization (AFNOR). The LOQ in an e-liquid for $\mathrm{As}=0.069, \mathrm{Cd}=0.001, \mathrm{Hg}=0.051$, $\mathrm{Pb}=0.032$ and $\mathrm{Sb}=0.058 \mathrm{ppm}$. The concentrations in e-cig solutions of six heavy metals ( $\mathrm{Zn}, \mathrm{Pb}, \mathrm{Ni}, \mathrm{Fe}, \mathrm{Cd}$ and $\mathrm{Cr}$ ) were calculated by Chae-Jin Na et al. (2019) to examine their relationship with e-cig consumption trends. Finally, a new systematic review was published in 2020 by Di Zhao et al. (2020) referred to the previous researchers (Monique et al. 2015; Williams et al. 2017).

\section{Flame atomic absorption spectroscopy (FAAS)}

FAAS is method of analysis of the concentration of over 62 different metals in a solution, and a sensitive in the ppm range. Schober et al. (2014) studied many trace elements such as $\mathrm{Al}, \mathrm{Cd}, \mathrm{Cr}, \mathrm{Cu}, \mathrm{Fe}, \mathrm{Mn}, \mathrm{Mg}, \mathrm{Ni}, \mathrm{Ti}, \mathrm{V}$ and $\mathrm{Zn}$. The dry weight analyzed varied from $1.33-3.61 \mathrm{mg} \mathrm{g}^{-1}$ on average, with $2.46 \mathrm{mg} \mathrm{g}^{-1}$ in different brands of e-cig. In 2016 , Mc Adam et al. (Flora et al. 2016), he studied 150 investigated measurements in e-cig aerosol. $\mathrm{Hg}, \mathrm{Cd}, \mathrm{Pb}, \mathrm{Se}, \mathrm{Co}, \mathrm{Be}$ and $\mathrm{Sn}$ were not found in blank samples of either e-cig spray or air system, although Ky3R4F MSS analysis revealed that $\mathrm{Cd}, \mathrm{Be}, \mathrm{Sn}$ and emissions were undetectable. In e-cig blank samples and air/process, $\mathrm{Cr}$, Ni and $\mathrm{Sn}$ not quantifiable emissions, but were quantifiable in Ky3R4F MSSS. E-cig emissions and vacuum air/method emissions are calculated to be 78 percent lower than these from Ky3R4F. Ni e-cig and Ky3R4F emissions were observed but not quantified, while Ni was not known from the air sample/method blank in one puff mass and was the other is not quantifiable. Prokopowicz et al. (2019) were determination blood $\mathrm{Cd}$ and $\mathrm{Pb}$ concentrations in trapped samples and e-liquids were performed by the electro-thermal atomic absorption spectrometry method. The research offers analytical evidence focused not only on the analysis of the aerosol produced, suggesting e-cig as a possible harm reduction device, in particular with respect to $\mathrm{Cd}$ exposure. Finally, a new systematic review was conducted by Di Zhao et al. in 2020 (2020) referred to the previous researchers (Margham et al. 2016; Lerner et al. 2015; Dunbar et al. 2018b).

\section{X-ray fluorescence spectroscopy (XRFS)}

One of the most effective methods for detecting and quantifying heavy and trace elements is XRF analysis (Erick et al. 2013). Goniewicz et al. (2014) analyzed 12 elements, detected only $\mathrm{Cd}, \mathrm{Ni}, \mathrm{Pb}$, and found in all vapors generated from 12 e-cigs brands. The results showed that $\mathrm{Cd}=0.01-0.22 \mathrm{mg}, \mathrm{Ni}=0.11-0.29 \mathrm{mg}$ and $\mathrm{Pb}=0.03-0.57 \mathrm{mg} / 150$ puffs in the one e-cig. In 2017, Christiani et al. (Mi-Sun et al. 2017) determined the concentrations of 48 trace elements in the $11 \mathrm{Na}$ to $82 \mathrm{~Pb}$ range of atomic numbers, $\mathrm{Ag}, \mathrm{Al}, \mathrm{As}, \mathrm{Au}, \mathrm{Ba}, \mathrm{Br}, \mathrm{Ca}, \mathrm{Cd}, \mathrm{Ce}, \mathrm{Cl}$, $\mathrm{Co}, \mathrm{Cr}, \mathrm{Cs}, \mathrm{Cu}, \mathrm{Eu}, \mathrm{Fa}, \mathrm{Ga}, \mathrm{Ge}, \mathrm{Hg}, \mathrm{K}, \mathrm{La}, \mathrm{In}, \mathrm{Mg}, \mathrm{Mo}, \mathrm{Na}$, $\mathrm{Nb}, \mathrm{Ni}, \mathrm{P}, \mathrm{Pb}, \mathrm{Pd}, \mathrm{Rb}, \mathrm{S}, \mathrm{Sb}, \mathrm{Sc}, \mathrm{Se}, \mathrm{Si}, \mathrm{Sm}, \mathrm{Sn}, \mathrm{Sr}, \mathrm{Tb}, \mathrm{Ti}$, $\mathrm{V}, \mathrm{W}, \mathrm{Y}, \mathrm{Zn}$, and Zr. Si, Cl, Ba and In were detected depending on the flavor and puffing time, while other metals were below the method's LOD. In 2018, Orkoula et al. (Eleni et al. 2018), the concentration of six heavy metals such as $\mathrm{As}, \mathrm{Cd}, \mathrm{Cr}, \mathrm{Cu}, \mathrm{Ni}$ and $\mathrm{Pb}$ was identified and determined in two sample series: A. e-liquids and B. constituents of e-liquids. The LOD was measured at $0.001 \mu \mathrm{g} / \mathrm{g}$ for $\mathrm{Ni}$ and $\mathrm{Cu}$, at $0.002 \mu \mathrm{g} / \mathrm{g}$ for $\mathrm{Cr}$, at less than $0.001 \mu \mathrm{g} / \mathrm{g}$ for $\mathrm{Pb}$ and As, and at $0.025 \mu \mathrm{g} / \mathrm{g} / \mathrm{g}$ for Cd. In order to quantify the concentrations of 48 trace elements including $\mathrm{Ag}, \mathrm{Al}, \mathrm{As}, \mathrm{Au}$, $\mathrm{Ba}, \mathrm{Br}, \mathrm{Ca}, \mathrm{Cd}, \mathrm{Ce}, \mathrm{Cl}, \mathrm{Co}, \mathrm{Cr}, \mathrm{Cs}, \mathrm{Cu}, \mathrm{Eu}, \mathrm{Fa}, \mathrm{Ga}, \mathrm{Ge}, \mathrm{K}$, $\mathrm{Pa}, \mathrm{In}, \mathrm{Mn}, \mathrm{Mo}, \mathrm{Na}, \mathrm{Ni}, \mathrm{P}, \mathrm{Pb}, \mathrm{Pd}, \mathrm{Rb}, \mathrm{S}, \mathrm{Sb}, \mathrm{Sc}, \mathrm{Se}, \mathrm{Si}$, Sn, Sr, Tb, Ti, Tl, V, W, Y, Zn and Zr. Christiani et al. (2017) (Mi-Sun et al. 2017), an energy-dispersive X-ray fluorescence (EDXRF) spectrometer was used. The results showed that trace elements such as $\mathrm{Ba}, \mathrm{Cl}$, In and Si depending on the flavor and buffing period, they have been found, while there were others below LOD. Trace amounts of harmful elements such as $\mathrm{Cd}, \mathrm{Ni}$ and $\mathrm{Pb}$ have been found in e-cig emissions in previous research, but the same metals have been detected in blank samples as well (Goniewicz et al. 2014; Margham et al. 2016).

\section{Molecular fluorescence spectroscopy (MFS)}

MF is measured by exciting the sample at the absorption wavelength, and measuring the emission at a longer wavelength. (Joseph 2010). In previous Argentinian research, Fernández group has developed alternative analytical methods to estimate traces of elements $\mathrm{Pb}, \mathrm{Cd}$ and $\mathrm{Ni}$ in e-cig refillable solutions. In 2015, Fernández et al. (María et al. 2015) suggested a new approach for evaluating traces of $\mathrm{Pb}^{2+}$ depending on the raise of the fluorescent signal of rhodamine-B $(\mathrm{RhB})$ dye as a fluorophore reagent in coacervate phase formation using cationic surfactant acetyl 
trimethyl ammonium bromide (CTAB) and potassium iodine as an agent for increasing ionic strength. The process demonstrated high sensitivity, sufficient selectivity and good resistance to foreign ions. The calibration graph using zero-order regression was linear from $7.4 \times 10^{-4}$ to $3.4 \mu \mathrm{g} / \mathrm{L}$, $\mathrm{LOD}=2.2 \times 10^{-4} \mu \mathrm{g} / \mathrm{L}$ and $\mathrm{LOQ}=7.4 \times 10^{-4} \mu \mathrm{g} / \mathrm{L}$. A new technique for the isolation and pre-concentration of $\mathrm{Ni}^{2+}$ and $\mathrm{Cd}^{2+}$ in many and varied nicotine, molasses and refilling options for samples of e-cig was developed in 2017 by Fernández et al. (Talio et al. 2017), solid surface fluorescence (SSF) was calculated at $\lambda_{\mathrm{em}}=545 \mathrm{~nm}\left(\lambda_{\mathrm{ex}}=515 \mathrm{~nm}\right)$ for the $\mathrm{Ni}^{2+}-\mathrm{E}_{\mathrm{o}}$ complex, and the $\mathrm{Cd}^{2+}-\mathrm{E}_{\mathrm{o}}$ fluorescence was quantified using $\lambda_{\mathrm{em}}=565 \mathrm{~nm}\left(\lambda_{\mathrm{ex}}=540 \mathrm{~nm}\right)$ in an aqueous solution. This technique demonstrated strong sensitivity, sufficient selectivity and was successfully applied with acceptable results to the determination of trace quantities of $\mathrm{Ni}$ and $\mathrm{Cd}$ present in tobacco samples e-cig refill solutions, snuff used in narguille molasses and conventional tobacco. The calibration graphs for $\mathrm{Ni}^{2+}$ resulted in a linear range of $0.058-29.35 \mu \mathrm{g} / \mathrm{L}$ and $0.124-56.20 \mu \mathrm{g} / \mathrm{L}$ for $\mathrm{Cd}^{+2}$, $\mathrm{LOD}=0.019$ and $0.041 \mu \mathrm{g} / \mathrm{L}(\mathrm{S} / \mathrm{N}=3)$. In 2019, Fernández et al. (María Carolina et al. 2019) established a new technique for evaluating $\mathrm{Pb}$ traces based on the quenching effect of the metal with 8-hydroxyquinoline and o-phenanthroline at $\lambda_{\mathrm{em}}=365 \mathrm{~nm}\left(\lambda_{\mathrm{exc}}=250 \mathrm{~nm}\right)$ on fluorescent emission of the complex. This technique demonstrated good sensitivity, sufficient selectivity and strong foreign ion resistance and was extended to the assessment of trace quantities of $\mathrm{Pb}$ in tobacco leachate and e-cig fill solutions with appropriate outcomes. The calibration graph using zero-order regression was linear from 1.21 to $518 \mu \mathrm{g} \mathrm{L}^{-1}$, with the correlation coefficient better than 0.999 . $\mathrm{LOD}=0.42 \mu \mathrm{g} \mathrm{L}^{-1}$, $\mathrm{LOQ}=1.21 \mu \mathrm{g} \mathrm{L}^{-1}$.

\section{Scanning electron microscopy (SEM) and electron dispersion spectroscopy (EDS)}

SEM-EDS is a type of electron microscope that creates sample images by scanning the surface with a directed electron beam. (Monique et al. 2015) studied $\mathrm{Sn}, \mathrm{Cr}, \mathrm{Cu}, \mathrm{Ni}, \mathrm{Ag}$ and $\mathrm{Zn}$ quantities in the aerosol of three cartomizers from each of the sample labels used in the analysis. In general, except for $\mathrm{Sn}$, concentrations were below $0.20 \mu \mathrm{g} / 10 \mathrm{puffs}$, and elements were not detectable in some cases. It detected only $\mathrm{Cu}$ and $\mathrm{Sn}$. There were minimal or undetectable amounts of $\mathrm{Ag}$. $\mathrm{Zn}$ values ranged from below the quantification mark to $0.127 \mu \mathrm{g} / 10$ puffs. $\mathrm{Cr}$ and $\mathrm{Ni}$ were either not detected or were detected at relatively low levels. Sn was the most variable element getting comparatively low tin concentrations, range $=0$ to $0.036 \mu \mathrm{g} / 10 \mathrm{puffs}$, on average, one brand had between 100 and 1000 times as much $\mathrm{Sn}$ as the other three labels. Tin concentrations ranged with a high concentration of $11.3 \mu \mathrm{g} / 10 \mathrm{puffs}$ for certain cartomizers and a low concentration of $0.398 \mu \mathrm{g} / 10$ puffs for the others. Williams et al. (2017) identified 36 inorganic chemical elements and quantities thereof in aerosols of e-cig/e-h. Filament; Ni, $\mathrm{Cr}$, thick wire; $\mathrm{Ag}$-coated $\mathrm{Cu}$, brass clamp; $\mathrm{Cu}, \mathrm{Zn}$, solder joints; $\mathrm{Sn}, \mathrm{Pb}$, and so wick and sheath were the elements that tended to come from $\mathrm{Al}, \mathrm{Ca}, \mathrm{Mg}, \mathrm{O}_{2}$, and $\mathrm{Si}$. In the solder and aerosol of two brands of e-hs, lead was detected, up to $0.165 \mu \mathrm{g} / 10$ puffs. The relative abundances of elements with concentrations above $0.002 \mu \mathrm{g} / 10$ puffs in e-cig aerosols using five brands of disposable e-cigs. The relative amounts of nine trace metals: $\mathrm{Al}, \mathrm{As}, \mathrm{Cd}, \mathrm{Cu}, \mathrm{Fe}, \mathrm{Mn}, \mathrm{Ni}$, $\mathrm{Pb}, \mathrm{Zn}$, and for each MCE membrane. The percentages and the total numbers of carbon atoms, oxygen and nitrogen, control: $n=9$, which are taken by Dominic et al. (2017), the volume of e-cig-generated trace metals was smaller than in the typical mainstream smoke with $\mu \mathrm{g}$ contents, and just Ni was higher in e-cig-generated aerosol than in control aerosol. Naudia et al. (2019), a validated method for quantitative analysis of toxic metals in ENDS liquids is also described. Until touching a device, refilling liquids for all metals are well below the owest reportable level (LRL). $\mathrm{Cu}$ and $\mathrm{Zn}$ were raised from devices containing brass in liquids. In all liquids, Cd was minimized LRL and has not been observed in device components. Ranged from low LRL to $\mathrm{Cr}=0.396, \mathrm{Cu}=903, \mathrm{Ni}=4.04, \mathrm{~Pb}=13.5, \mathrm{Sn}=0.898$ and $\mathrm{Zn}=454 \mu \mathrm{g} / \mathrm{g}$. Williams et al. (2019a) identified eight metals periods inside various brands. $\mathrm{Al}, \mathrm{Cr}, \mathrm{Co}, \mathrm{Ni}, \mathrm{Si}, \mathrm{Ag}, \mathrm{Sn}$, and $\mathrm{Zn}$. In cartomizer and tank models, the metals used in different parts were often identical. The filaments were typically $\mathrm{Cr}$ and Ni nichrome, but the filament often included $\mathrm{Fe}$, $\mathrm{Cu}$ and $\mathrm{Mn}$ in some newer products. The thick wire in older products was typically $\mathrm{Ag}$-coated $\mathrm{Cu}$, whereas the thick wire was mostly nickel in some newer products. The wick was silica in all products, and the sheaths, as available, were fiberglass $\mathrm{Si}, \mathrm{O}_{2}, \mathrm{Ca}, \mathrm{Al}, \mathrm{Mg}$. Wire-to-wire joints have either been brazed or brass-clamped $\mathrm{Cu}$ and $\mathrm{Zn}$. Particle sizes have been determined by (Steven et al. 2020), for $\mathrm{Cr}, \mathrm{Cu}, \mathrm{Fe}, \mathrm{Pb}$, $\mathrm{Ni}, \mathrm{Sn}$ and $\mathrm{Zn}$ oxides. Found that the pods of both manufacturers had $80-85 \% \mathrm{Ni}$, and $15-20 \% \mathrm{Au}$, as elements of the electrical connector surface alloys. Particle sizes have been determined by Pappas et al. (2020) for $\mathrm{Cr}, \mathrm{Cu}, \mathrm{Fe}, \mathrm{Pb}, \mathrm{Ni}$, $\mathrm{Sn}$ and $\mathrm{Zn}$ oxides (Steven et al. 2020). Found that the pods of both manufacturers had $80-85 \% \mathrm{Ni}$, and $15-20 \% \mathrm{Au}$, as elements of the electrical connector surface alloys.

\section{Mass spectrometry (MS)}

The detector of MS is capable of achieving greater sensitivity and precision, allowing the qualitative and quantitative detection of detectable amounts of targeted material, but at higher costs and technological skills (Stone et al. 2008). In order to test and compare indoor emission levels of chemical species during e-cig vaping and normal cigarette smoking, 
Saffari et al. (2014) used a single-compartment mass balance model. $\mathrm{Cd}$ - and $\mathrm{Pb}$-based indoor pollution concentrations during normal cigarette smoking were as elevated as $1012 \mathrm{ng} / \mathrm{h}$ for $\mathrm{Pb}$ and $657 \mathrm{ng} / \mathrm{h}$ for $\mathrm{Cd}$, although these rates are lower by $2-3$ magnitude orders for e-cig vaping. Similarly, for ordinary cigs, sulfur had an indoor pollution average of around $34 \mathrm{mg} \mathrm{h}^{-1}$. For normal cigarette smoking, the indoor emission rate of all components was greater compared to e-cig vaping, with the exception of $\mathrm{Ni}, \mathrm{Ti}, \mathrm{Cr}$ and Ag. This finding indicates that while the aerosols of e-cigs contain many metals like $\mathrm{Ag}, \mathrm{Cr}$ and $\mathrm{Ni}$ that are released from e-cig at higher concentrations. In addition, e-cig emissions of $\mathrm{Pb}$ were significantly reduced relative to regular cigs.

\section{Composition analysis, TEM images and EDX maps}

By (Mark et al. 2019) characterizing both size and quantity of generated nanoparticles and their chemical compositions. The particle's TEM picture is paired with the EDX map. The maps correspond to $\mathrm{Al}, \mathrm{Cr}, \mathrm{Fe}, \mathrm{O}, \mathrm{Mn}$ and $\mathrm{Si}$. Under each operating environment, the number of produced particles decreased dramatically within the first 15-min of each test run. Steven et al. (2020) performed a modified TEM image visual analysis, mostly displaying agglomerated individual particles rather than discrete particle images. However, for individual nanopowders, SP-ICP-MS provided the most normal size or mean size results with the use of acceptable sonic times of up to $30 \mathrm{~min}$, which were very similar to the product's specified particle sizes with a few exceptions. The most common sizes (size distribution peaks) for $\mathrm{Cr}_{2} \mathrm{O}_{3} 60 \mathrm{~nm}$ and $\mathrm{Fe}_{2} \mathrm{O}_{3} 23 \mathrm{~nm}$. After $10 \mathrm{~min}$ of sonication, the apparent size of the $\mathrm{Ni}_{2} \mathrm{O}_{3}$ particle leveled out. The most common $33 \mathrm{~nm}$ $\mathrm{CuO}$ particle size calculated by SP-ICP-MS was within the manufacturer's $25-55 \mathrm{~nm}$ size range. The mean particle concentrations for $\mathrm{ZnO}$ were low in comparison with other metal oxides, but increased by up to $10 \mathrm{~min}$ of sonification before decreasing. The most popular $\mathrm{Pb}_{2} \mathrm{O}_{3}$ particle size was $28 \mathrm{~nm}$ at $1 \mathrm{~min}$ sonic time, within the range shown by the manufacturer. For all sonic intervals above $1 \mathrm{~min}$, the particle number of $\mathrm{Pb}_{2} \mathrm{O}_{3}$ decreased, as the limits of particle detection expanded because of dissolved background. As was the case with $\mathrm{ZnO}$, until decreasing to $30 \mathrm{~min}$, the most frequent and mean particle sizes increased between 1 and 15 min sonic intervals. At 10 min of sonication time, the mean very frequent particle size of $\mathrm{SnO}_{2}$ was $35 \mathrm{~nm}$, within the size range indicated by the maker. In $10 \mathrm{~min}$, the average particle size reached a limit of $52 \mathrm{~nm}$, even beyond the maker's prescribed size range. In 2016, Lerner et al. (Chad et al. 2016), using semi-quantitative methods to detect oxidant reactivity or nanoparticles, have recently been reported as components of aerosols emitted from different e-cig types and found that metal nanoparticles $\mathrm{TiO}_{2}, \mathrm{CuO}, \mathrm{Cu}_{40}, \mathrm{C}_{60}$ were generated at $1 \mathrm{uM}$ for $15 \mathrm{~min}$ in accordance with the manufacturing instructions (Life Technologies). In disposable ENDS/e-cig parts, batteries and cartomizers, using a fluorescein detector. The cascade particle impacter permitted the sieving of a variety of particle size distributions between 0.450 and $2.02 \mu \mathrm{m}$ in e-cig aerosols. $\mathrm{Cu}=120 \mathrm{ng}$, being among these particles, is 6.1 times higher per puff than previously recorded for $\mathrm{CCs}$. $\mathrm{Cu}$ or $\mathrm{Ti}$ is found in e-cig aerosols. In order to decide whether these elements alone could affect mitochondrial ROS (mROS) levels, human lung fibroblasts (HFL-1) cells in culture were treated with $\mathrm{TiO}_{2}, \mathrm{CuO} 30 \mathrm{~nm}$ or metallic $\mathrm{Cu} 40$ and $60 \mathrm{~nm}$. Shen Hu et al. (2016) also showed in 2016 that the concentration of the PNC particle number of e-cig aerosols was observed to correspond favorably with the puff duration in gas phase, whereas the PNC and size distribution will vary with various nicotine flavors and intensity. In the liquid phase, water or cell culture media, the size of e-cig nanoparticles seemed to be considerably larger than these in the gas phase, which could be due to the concentration of nanoparticles in the liquid phase. Condensation particle counter, CPC 3785, TSI Inc., Shoreview, MN, and scanning mobility particle sizer, SMPS 3080, TSI Inc., Shoreview, MN, have been tested for the accumulation of particle numbers and the scale distribution of e-cig aerosols. The SMPS sampling rate was $0.6 \mathrm{~L} \mathrm{~min}^{-1}$, and the measuring spectrum was 7-289 nm, $100 \mathrm{~s}$ higher scan, $20 \mathrm{~s}$ lower scan. Right after each puff, the SMPS begins running. The particle measurements for each length of puff were repeated 5 times. The chamber was flushed with clean air for each measurement until the average concentration of the particles in the chamber was less than $1000 \mathrm{~cm}^{-3}$. Silicon, iron and sodium have been contained in particles of e-cig. Also, copper was detected, though not from nanoparticles, but by the grid of TEM. TEM was used for morphology monitoring and primary size assessment of e-cig aerosol nanoparticles. EDX determined the basic structure of the e-cig aerosols. The inductively coupled plasma-optical emission spectrometry ICP-OESES is measured for the quantitative elementary analysis of e-cig aerosols.

For bio-samples, in 2020, Di et al. (2020) published a recent systematic review referred to the previous researchers, such as three studies identified metal/metalloid levels in urine in micrograms per liter (Aherrera et al. 2017; Jain 2018), in micrograms per gram of creatinine(Jain 2018; Goniewicz et al. 2018b), and among the metal/metalloidlevel studies reported (Goniewicz et al. 2018b; Badea et al. 2018).

The range of aspiratory infection brought about by e-cig use (Layden et al. 2019). Examination of the gadget's e-fluid uncovered critical degrees of Co, supporting a conclusion of monster cell interstitial pneumonia related with breathed in Co from normal e-cig use. Coronavirus is causing wellbeing effects and disturbances internationally by Eric et al. 
(2020), e-cig use may put clients at risk due to increased exposure to people with COVID-19, which may be increased by exposure to toxic substances in e-cig aerosols such as increased exposure, financial burdens, stress and health risks. The relationship among vaping and COVID-19 has created a lot of interest (Berlin et al. 2020; Batlle et al. 2020; Guo et al. 2020), on which the potential role of nicotine in treating this epidemic is discussed, which was applied to the consistent results that prove the opposite for each of Russo et al. (2020), Leung et al. (2020a) and Brake et al. (2020a), the subsequent commentary by Leung et al. (2020b), Wrapp et al. (2020), Liu et al. (2020), Gilpin et al. (2019), Miyashita et al. (2018), Atto et al. (2019), Sohal et al. (2019) and Mc Alinden et al. (2019); on a fundamental level, the theory is that the SARS-CoV-2 infection is a nicotinic specialist which rivals nicotine for the receptor, the authors conclude that nicotine is a danger factor for coronavirus. The World Health Organization had issued warning dated May 4, 2020, regarding tobacco use during this pandemic (World Health Organization 2020). Unquestionably, the dangers of critical pneumonic injury with vaping are currently very much depicted in the writing (Werner et al. 2020), and the different ways that vaping can cause cell harm and hinder the lung's reaction to contamination are unmistakably portrayed by the creators. The hypothetical chance that vaping could take action lung for SARS-CoV-2 contamination is as yet speculative, offered that to date none of the epidemiological examinations have provided details regarding vaping predominance among their coronavirus patients.

Jasmine et al. (2020) concluded that COVID-19 ARDS has more terrible results when contrasted with ARDS because of different causes, there is ongoing exploration for treatment of COVID-19-related ARDS. Vaping increases pneumococcal adherence through an expansion in plateletinitiating factor receptor articulation, at last delivering the individuals who vape with an expanded danger of pneumonia (Miyashita et al. 2018; Atto et al. 2019). Coronavirus and movement of serious pneumonia might be bound to happen in smokers, especially in those that have smoking-related comorbidities (Liu et al. 2020). It raises the worry that all electronic nicotine delivery frameworks may put clients at more serious danger of capitulating to COVID-19 (Kielan et al. 2020). Darmawan et al. (2020) examine three adolescents who presented at hospitals with respiratory distress during COVID-19. In addition to demonstrating the common clinical symptoms of these two diseases, the authors urge clinicians to advise away from e-cig use and other vaping items - as the most ideal way to prevent lung injury. This study provides an important update that young adults who smoke e-cigs may be at double the risk of developing lung infections-from COVID-19 and new items. Kale et al. (2020) wrote in their study that a big part of current vapers changed their vaping utilization since COVID-19. Although there are very few studies on vaping and the risk of COVID19 disease, two studies reported that analyzing COVID-19 was more likely to occur among people who smoke e-cigs, confirming that they are at risk of contracting COVID-19 (Li et al. 2020; Gaiha et al. 2020).

In a new study by Farsalinos et al. (2021) (Konstantinos et al. 2021), on the prevalence of smoking with regular cigs and e-cigs among people with COVID-19 in China, this study does not consider nicotine to be a risk factor for infection with COVID-19. Rather, it considers that nicotine may have beneficial effects for eliminating COVID-19 (Li et al. 2020). There is proof that vaping impacts lung work, along these lines expanding the danger of COVID-19 contamination. Vaping items often contain nicotine and produce airborne rather than smoke (Pushalkar et al. 2020; Gotts et al. 2019), the use of vaping elements has been linked to lung damage (Brake et al. 2020b; Javelle 2020). In addition to nicotine, particulates and flavorings in e-cigs/vape sprays can likewise impair lung function (National Academies of Sciences 2018). Three review articles detailed vaping conduct that might be related to COVID-19 transmission, irrelevant to inhalation (Agency and for Health Protection and Promotion (Public Health Ontario) 2020a; Majmundar et al. 2020; Kampf et al. 2020). Vaping involves constant handto-mouth contact which may increase your chances of contracting COVID-19 (Agency and for Health Protection and Promotion (Public Health Ontario) 2020a; Majmundar et al. 2020). Recent information from exploratory scans tracks that the virus remains stable for a few hours to days on surfaces, making it possible to visualize transmission of infection via the surfaces of vaping devices (Agency and for Health Protection and Promotion (Public Health Ontario) 2020b). There is introductory evidence about the expected role of smoking as well as vaping on the infection and severity of COVID-19. And included investigations that showed that people who vape or smoke may be more likely to contract COVID-19 or need mechanical ventilation compared to nonsmokers (Kaur et al. 2020; Munzel et al. 2020; Archie and Cucullo 2020). There is a need to establish the effect of vaping on the lungs and whether this effect increases a person's susceptibility to COVID-19 infection and the severity of COVID-19 disease (Li et al. 2020; Lancet 2020; Galo et al. 2020). No wonder there are no studies showing a dangerous effect of heavy elements in e-cigarettes on people with COVID-19. Given that e-cigs appear to be less dangerous to the vaping user. It can be used to help quit smoking.

\section{Conclusions}

All sources indicate that an electronic cigarette is a source of toxicity for heavy metals and trace emissions from e-liquid, files or aerosols. They have no appreciable effect except as 
a cumulative effect over time. Because the minerals emitted from e-cigs are in very small (nanometer) concentrations and can be released in microscopic concentrations in rare cases. A variety of sophisticated techniques have been used to estimate these elements and there are still many techniques that can be used to estimate these elements. As for the studies that included the relationship between COVID-19 and vaping, they did not address the effect of heavy metals from e-cigs on infection with the coronavirus, which may be addressed in the future.

\section{References}

Aherrera A, Olmedo P, Grau-Perez M, Tanda S, Goessler W, Jarmul S (2017) The association of e-cigarette use with exposure to nickel and chromium: a preliminary study of non-invasive biomarkers. Environ Res 159:313-320. https://doi.org/10.1016/j.envres.2017. 08.014PMID:28837903 (PMID: 28837903)

Archie SR, Cucullo L (2020) Cerebrovascular and neurological dysfunction under the threat of COVID-19: is there a comorbid role for smoking and vaping? Int J Mol Sci 21(11):3916. https://doi. org/10.3390/ijms21113916

Ashraf MW (2011) Concentrations of cadmium and lead in different cigarette brands and human exposure to these metals via smoking. J Arts Sci Commer 2:140-147

Atto B, Eapen MS, Sharma P (2019) New therapeutic targets for the prevention of infectious acute exacerbations of COPD: role of epithelial adhesion molecules and inflammatory pathways. Clin Sci 133:1663-1703

Badea M, Luzardo OP, González-Antuña A, Zumbado M, Rogozea L, Floroian L (2018) Body burden of toxic metals and rare earth elements in non-smokers, cigarette smokers and electronic cigarette users. Environ Res 166:269-275. https://doi.org/10.1016/j. envres.2018.06.007 (PMID: 29908458)

Bansal V, Kim KH (2016) Review on quantitation methods for hazardous pollutants released by e-cigarette (EC) smoking. Trac-Trend Anal Chem 78:120-133. https://doi.org/10.1016/j.trac.02.015

Batlle D, Wysocki J, Satchell K (2020) Soluble angiotensin-converting enzyme 2: a potential approach for coronavirus infection therapy? Clin Sci 134:543-545

Beauval N, Howsam M, Antherieu S, Allorge D, Soyez M, Garçon G (2016) Trace elements in e-liquids — development and validation of an ICP-MS method for the analysis of electronic cigarette refills. Regul Toxicol Pharmacol 79:144-148. https://doi.org/10. 1016/j.yrtph.2016.03.024 (PMID: 27058761)

Beauval N, Antherieu S, Soyez M, Gengler N, Grova N, Howsam M (2017) Chemical evaluation of electronic cigarettes: multicomponent analysis of liquid refills and their corresponding aerosols. J Anal Toxicol 41(8):670-678. https://doi.org/10.1093/jat/bkx054 (PMID: 28985322)

Berg CJ, Barr DB, Stratton E, Escoffery C, Kegler M (2014) Attitudes toward e-cigarettes, reasons for initiating e-cigarette use, and changes in smoking behavior after initiation: a pilot longitudinal study of regular cigarette smokers. Open J Prev Med 4(10):789-800

Berlin I, Thomas D, Le Faou AL (2020) COVID-19 and smoking. Nicotine Tob Res in press https://doi.org/10.1093/ntr/ntaa059

Bertholon JF, Becquemin MH, Roy M, Roy F, Ledur D, Annesi M (2013) Comparison of the aerosol produced by electronic cigarettes with conventional cigarettes and the shisha]. Rev Mal Respir 30:752-757
Bertrand L, Maud C (2018) Analysis of heavy metals in e-liquids using the Agilent 5110 ICP-OES. Agilent Technologies, Inc

Biagio T, Roberta P, Alessandra DP, Ilaria P, Renata S, Fabrizio F, Giuseppe G (2013) Focus on electronic cigarettes. Epidemiol Prev 37(4-5):303-307

Brake SJ, Barnsley K, Lu W, McAlinden KD, Eapen MS, Sohal SS (2020b) Smoking upregulates angiotensin-converting enzyme-2 receptor: a potential adhesion site for novel coronavirus SARS-CoV-2 (covid-19). J Clin Med 9(3):841. https:// doi.org/10.3390/jcm9030841

Brake SJ, Barnsley K, Lu W (2020a) Smoking upregulates angiotensin-converting enzyme- 2 receptor: a potential adhesion site for novel coronavirus SARS-CoV-2 (Covid-19). J Clin Med 9:841

Brown CJ, Cheng JM (2014) Electronic cigarettes: product characterization and design considerations. Tob Control 23(Suppl 2):ii4-10

Brown RJC, Milton MJT (2005) Analytical techniques for trace element analysis: an overview. Trends Anal Chem 24:266-274. https://doi.org/10.1016/j.trac.2004.11.010

Chad A, Lerner PR, Tanveer A, Isaac K, Sundar AE, Irfan R (2016) Electronic cigarette aerosols and copper nanoparticles induce mitochondrial stress and promote DNA fragmentation in lung fibroblasts. Biochem Biophys Res Commun 477(4):620-625. https://doi.org/10.1016/j.bbrc.2016.06.109

Chae-Jin N, Sang-Hee J, Ki-Hyun K, Jong-Ryeul S, Youn-Suk S (2019) The transfer characteristics of heavy metals in electronic cigarette liquid. Environ Res J homepage. www.elsevier.com/locate/ envres, 174 152-159

Charles BB, Kenneth JF (2004) Concepts instrumentation and techniques in inductively coupled plasma optical emission spectrometry, 3rd ed. Perkin Elmer, pp 69-82

Charlotta P, MD, PhD, MPH (2015) A systematic review of health effects of electronic cigarettes. Research Centre for Prevention and Health, Glostrup Hospital, Glostrup, Denmark

Cheng T (2014) Chemical evaluation of electronic cigarettes. Tob Control 23:ii11-ii17. https://doi.org/10.1136/tobaccocon trol-2013-051482

Chuo YT, Nawaltul Akma AS, Lee Len T, Hazalinawati Z, Li PW, Nasrin AM, Lawrence A (2019) Heavy metals (Cr, Pb, Cd, Ni) in aerosols emitted from electronic cigarettes sold in Malaysia. J Environ Sci Health, Part A 10(1080/10934529): 1665950

Dai J et al (2017) A simple method for the parallel quantification of nicotine and major solvent components in electronic cigarette liquids and vaped aerosols. Microchem J 133:237-245

Darmawan et al. (2020) Vaping in today's pandemic: E-cigarette, or vaping, product-use associated lung injury mimicking COVID19 in teenagers representing with respiratory distress. Sage Open Medical Case Reports, Volume 8

Di Z, Atul A, Markus H, Pablo O, Ana MR, Ana N-A, Angela A (2020) Metal/metalloid levels in electronic cigarette liquids, aerosols, and human biosamples: a systematic review. Environ Health Perspect. https://doi.org/10.1289/EHP5686

Dominic LP, Andrew PC, John MN, Robert AJ (2017) Trace metals derived from electronic cigarette (ECIG) generated aerosol: potential problem of ECIG devices that contain nickel, clinical and translational physiology, a section of the Journal Frontiers in Physiology, vol 7

Dunbar ZR, Das A, O'Connor RJ, Goniewicz ML, Wei B, Travers MJ (2018a) Brief report: lead levels in selected electronic cigarettes from Canada and the United States. Int J Environ Res Public Health 15(1):154. https://doi.org/10.3390/ijerph15010154 (PMID: 29351185)

Dunbar ZR, Das A, O'Connor RJ, Goniewicz ML, Wei B, Travers MJ (2018b) Brief report: lead levels in selected electronic cigarettes from Canada and United states. Int J Environ Res Public Health 15:154. https://doi.org/10.3390/ijerph15010154 
Eleni K, Konstantinos F, Konstantinos P, Christos GK, Malvina GO (2018) Detection and quantitative determination of heavy metals in electronic cigarette refill liquids using Total Reflection X-ray Fluorescence Spectrometry. Food Chem Toxicol 116(2):233-237. https://doi.org/10.1016/j.fct.2018.04.035 (PMID: 29679608, (18)30243-6)

Eric KS, Shannon M, William S, Mignonne CG, Alison B, Pebbles F (2020) Impacts of COVID-19 on electronic cigarette purchasing, use and related behaviors. Int J Environ Res Public Health 17:6762. https://doi.org/10.3390/ijerph17186762

Erick KT, Keith DS, Geory C (2013) Quantification of total element concentration in soil using X-Ray fluoresce spectroscopy. J Sci Total Environ 463:374-388

Fels Elliott DR, Shah R, Hess CA (2019) Giant cell interstitial pneumonia secondary to cobalt exposure from e-cigarette use. Eur Respir J 54:1901922. https://doi.org/10.1183/13993003.01922-2019

Flora JW, Meruva N, Huang CB, Wilkinson CT, Ballentine R, Smith DC (2016) Characterization of potential impurities and degradation products in electronic cigarette formulations and aerosols. Regul Toxicol Pharmacol 74:1-11. https://doi.org/10.1016/j. yrtph.2015.11.009 (PMID: 26617410)

Fuoco FC, Buonanno G, Stabile L, Vigo P (2014) Influential parameters on particle concentration and size distribution in the mainstream of e-cigarettes. Environ Pollut 184:523-529. https://doi. org/10.1016/j.envpol.2013.10.010

Gaiha SM, Cheng J, Halpern-Felsher B (2020) Association between youth smoking, electronic cigarette use, and coronavirus disease 2019. J Adolesc Health 67(4):519-523. https://doi.org/10.1016/j. jadohealth.2020.07.002

Galo J, Celli D, Gross D, Holt G, Campos M (2020) A presentation of e-cigarette vaping associated lung injury (EVALI) caused by THC-containing electronic smoking device. Respir Med Case Rep 31:101154. https://doi.org/10.1016/j.rmcr.2020.101154

Gilpin DF, McGown KA, Gallagher K (2019) Electronic cigarette vapour increases virulence and inflammatory potential of respiratory pathogens. Respir Res 20:267

Glasser AM, Collins L, Pearson JL, Abudayyeh H, Niaura RS, Abrams DB, Villanti AC (2017) Overview of electronic nicotine delivery systems: a systematic review. Am J Prev Med 52(2):e33e66. https://doi.org/10.1016/j.amepre.2016.10.036 ([PMID: 27914771])

Goniewicz ML, Knysak J, Gawron M (2014) Levels of selected carcinogens and toxicants in vapour from electronic cigarettes. Tob Control 23(2):133-139. https://doi.org/10.1136/tobaccocontrol2 012-050859

Goniewicz ML, Smith DM, Edwards KC, Blount BC, Caldwell KL, Feng $\mathrm{J}$ (2018b) Comparison of nicotine and toxicant exposure in users of electronic cigarettes and combustible cigarettes. JAMA Netw Open 1(8):e185937. https://doi.org/10.1001/jamanetwor kopen.2018.5937 (PMID: 30646298)

Goniewicz ML, Boykan R, Messina CR, Eliscu A, Tolentino J (2018a) High exposure to nicotine among adolescents who use Juul and other vape pod systems ('pods'). Tob Control. https://doi.org/10. 1136/tobaccocontrol-2018-054565

Gotts JE, Jordt S, McConnell R, Tarran R (2019) What are the respiratory effects of e-cigarettes? BMJ 366:15275. https://doi.org/10. 1136/bmj. 15275

Gray N, Halstead M, Gonzalez-Jimenez N, Valentin-Blasini L, Watson C, Pappas RS (2019) Analysis of toxic metals in liquid from electronic cigarettes. Int J Environ Res Public Health 16:4450 ([CrossRef])

Guo J, Huang Z, Lin L (2020) Coronavirus disease 2019 (COVID-19) and cardiovascular disease: a viewpoint on the potential influence of angiotensin-converting enzyme inhibitors/angiotensin receptor blockers on onset and severity of severe acute respiratory syndrome coronavirus 2 infection. J Am Heart Assoc 9:e016219
Hess CA, Olmedo P, Navas-Acien A, Goessler W, Cohen JE, Rule AM (2017) E-cigarettes as a source of toxic and potentially carcinogenic metals. Environ Res 152:221-225. https://doi.org/10. 1016/j.envres.2016.09.026 (PMID: 27810679)

Huang J, Duan Z, Kwok J, Binns S, Vera L (2019) Vaping versus JUULing: how the extraordinary growth and marketing of JUUL transformed the US retail e-cigarette market. Tob Control 28:146-151 ([PubMed: 29853561])

Ingebrethsen BJ, Cole SK, Alderman SL (2012) Electronic cigarette aerosol particle size distribution measurements. Inhal Toxicol Int Forum Respir Res 24(14):976-984. 45. https://doi.org/10.3109/ 08958378.2012.744781

Jain RB (2018) Concentrations of selected metals in blood, serum, and urine among US adult exclusive users of cigarettes, cigars, and electronic cigarettes. Toxicol Environ Chem 100(1):134-142. https://doi.org/10.1080/02772248.2018.1426764

Jasmine S, Divya V, Kendall C, Hazim B (2020) ARDS related to COVID-19. October 2020, Chest 158(4):A2565. https://doi.org/ 10.1016/j.chest.2020.09.162

Javelle E (2020) Electronic cigarette and vaping should be discouraged during the new coronavirus SARS-CoV-2 pandemic. Arch Toxicol 94(6):2261-2262. https://doi.org/10.1007/ s00204-020-02744-z

Jeffrey JK, Nicole S, Wojtek T, Anthony G, Stanislav F, Ian S, Joshua W, Denis R, John MO (2017) Universal electronic-cigarette test: physiochemical characterization of reference e-liquid. Tob Induc Dis 15:14. https://doi.org/10.1186/s12971-017-0119-x

Ji EH, Sun B, Zhao T, Shu S, Chang CH, Messadi D, Xia T, Zhu Y, Hu S (2016) Characterization of electronic cigarette aerosol and its induction of oxidative stress response in oral keratinocytes. PLoS ONE. https://doi.org/10.1371/journal.pone.0154447

Joseph R L (2010) Principles of fluorescence spectroscopy, 3ed. University of Maryland School of Medicine Baltimore, Maryland, USA. Printing

Julia C, Chen-Sankey ID, Grace K, Kelvin C (2019) Perceived ease of flavored e-cigarette use and e-cigarette use progression among youth never tobacco users. PLOS ONE. https://doi.org/10.1371/ journal.pone.0212353. 27 Feb 2019

Kale D, Herbec A, Perski O, Shahab L (2020) Associations between vaping and Covid-19: cross-sectional findings from the HEBECO study. It is made available under a CC-BY-NC-ND 4.0 International license (which was not certified by peer review) is the author/funder, who has granted medRxiv a license to display the preprint in perpetuity. mDecember 2020. https://doi.org/10.1101/ 2020.12.01.20241760

Kamilari E, Farsalinos K, Poulas K, Kontoyannis CG, Orkoula MG (2018) Detection and quantitative determination of heavy metals in electronic cigarette refill liquids using Total Reflection X-ray Fluorescence Spectrometry. Food Chem Toxicol 116(PtB):233-237. https://doi.org/10.1016/j.fct.2018.04.035 (PMID: 29679608)

Kampf G, Todt D, Pfaender S, Steinmann E (2020) Persistence of coronaviruses on inanimate surfaces and their inactivation with biocidal agents. J Hosp Infect 104(3):246-251. https://doi.org/ 10.1016/j.jhin.2020.01.022

Kaur G, Lungarella G, Rahman I (2020) SARS-CoV-2 COVID19 susceptibility and lung inflammatory storm by smoking and vaping. J Inflamm (lond) 17:21. https://doi.org/10.1186/ s12950-020-00250-8

Kielan D, Mc Alinden, Mathew SE, Lu W, Collin C, Greg H, Sukhwinder SS (2020) COVID-19 and vaping: risk for increased susceptibility to SARS-CoV-2 infection? Eur Respir J 56(1):2001645. https://doi.org/10.1183/13993003.01645-2020

Konstantinos EF, Anastasia B, Raymond N (2021) Smoking, vaping and hospitalization for COVID-19, Farsalinos et al. Harm Reduct J 18:9. https://doi.org/10.1186/s12954-020-00437-5 
Lancet RM (2020) The EVALI outbreak and vaping in the COVID-19 era. Lancet Respir Med 8(9):831. https://doi.org/10.1016/s22132600(20)30360-x

Laugesen M (2008) Safety Report on the Ruyan E-cigarette Cartridge and Inhaled Aerosol. Christchurch, New Zealand: Health New Zealand Ltd. http://www.healthnz.co.nz/Ruyan.Cartridge.Repor t30-Oct-08.pdf. Accessed 30 Sept 2014

Laugesen M (2009) Ruyane-cigarette bench-top tests [abstract]. Society for Research on Nicotine and Tobacco (SRNT)

Layden JE, Ghinai I, Pray I (2019) Pulmonary illness related to e-cigarette use in Illinois and Wisconsin-preliminary report. N Engl J Med; in press. https://doi.org/10.1056/NEJMoa1911614

Lerner CA, Sundar IK, Watson RM, Elder A, Jones R, Done D (2015) Environmental health hazards of e-cigarettes and their components: oxidants and copper in e-cigarette aerosols. Environ Pollut 198:100-107. https://doi.org/10.1016/j.envpol.12.033 (PMID: 25577651)

Leung JM, Yang CX, Tam A (2020a) ACE-2 expression in the small airway epithelia of smokers and COPD patients: implications for COVID-19. Eur Respir J 55:200688

Leung JM, Yang CX, Sin DD (2020b) COVID-19 and nicotine as a mediator of ACE-2. Eur Respir J 55:2001261

Levy DT, Borland R, Lindblom EN, Goniewicz ML, Meza R, Holford TR, Abrams DB (2018) Potential deaths averted in USA by replacing cigarettes with e-cigarettes. Tob Control 27:18-25. https://tobaccocontrol.bmj.com/content/27/1/18. Accessed 28 Nov 2019. https://doi.org/10.1136/tobaccocontrol-2017-053759

Li D, Croft DP, Ossip DJ, Xie Z (2020) Are vapers more susceptible to COVID-19 infection? MedRxiv 20092379 [Preprint]. 2020 May 09 [cited 2020 Sep 15]. https://doi.org/10.1101/2020.05. 05.20092379

Li D, Croft DP, Ossip DJ, Xie Z (2020) The association between statewide vaping prevalence and COVID-19. Preventive Medicine Reports, 20 101254, journal homepage. www.elsevier.com/ locate/pmedr

Liu W, Tao Z-W, Wang L (2020) Analysis of factors associated with disease outcomes in hospitalized patients with 2019 novel coronavirus disease. Chin Med J 133:1032-1038

Majmundar A, Allem JP, Cruz TB, Unger JB (2020) Public health concerns and unsubstantiated claims at the intersection of vaping and COVID-19. Nicotine Tobacco Res 22(9):1667-1668. https:// doi.org/10.1093/ntr/ntaa064

Manigrasso M, Buonanno G, Fuoco FC, Stabile L, Avino P (2015) Aerosol deposition doses in the human respiratory tree of electronic cigarette smokers. Environ Pollut 196:257-267. https:// doi.org/10.1016/j.envpol.2014.10.013

Margham J, Mc Adam K, Forster M, Liu C, Wright C, Mariner D (2016) Chemical composition of aerosol from an e-cigarette: a quantitative comparison with cigarette smoke. Chem Res Toxicol 29(10):1662-1678. https://doi.org/10.1021/acs.chemrestox. 6b00188 (PMID: 27641760)

María CT, Karen Z, Marcos K, Mariano A, Raúl AG, Marta OL, Liliana PF (2015) New solid surface fluorescence methodology for lead traces determination using rhodamine $\mathrm{B}$ as fluorophore and coacervation scheme: Application to lead quantification in e-cigarette refill liquids. Talanta 143:315-319. https://doi.org/10. 1016/j.talanta.2015.04.078 (PMID: 26078165)

María Carolina T, Fernando P, Mariano A, Liliana PF (2019) Lead monitoring and control in tobacco products and E-cigarettes by molecular fluorescence. Microchem J 147:1-6

Mark DW, Kaushal AP, Jong SK, Jae HP (2019) Characteristics of metallic nanoparticles emitted from heated Kanthal e-cigarette coils. J Nanoparticle Res volume 21, Article number: 156

Mary H, Naudia G, Nathalie G-J, Mark F, Liza V-B, Clifford W, Steven PR (2019) Analysis of Toxic Metals in Electronic Cigarette
Aerosols Using a Novel Trap Design. J Anal Toxicol 00:1-7. https://doi.org/10.1093/jat/bkz078 (Review paper)

Mc Alinden KD, Sohal SS, Sharma P (2019) There can be smoke without fire: warranted caution in promoting electronic cigarettes and heat not burn devices as a safer alternative to cigarette smoking. ERJ Open Res 5:00114-02019

McKelvey K, Baiocchi M, Halpern-Felsher B (2018) Adolescents' and young adults' use and perceptions of pod-based electronic cigarettes. JAMA Netw Open 1:e183535 ([PubMed: 30646249])

Mikheev VB, Brinkman MC, Granville CA, Gordon SM, Clark PI (2016) Real-time measurement of electronic cigarette aerosol size distribution and metals content analysis. Nicotine Tob Res 18(9):1895-1902. https://doi.org/10.1093/ntr/ntw128 (PMID: 27146638)

Mi-Sun L, Ryan FLB, Youn-Suk S, Petros K, David CC (2017) Nicotine, aerosol particles, carbonyls and volatile organic compounds in tobacco and menthol-flavored e-cigarettes. Environ Health 16:42. https://doi.org/10.1186/s12940-017-0249-x

Miyashita L, Suri R, Dearing E (2018) E-cigarette vapour enhances pneumococcal adherence to airway epithelial cells. Eur Respir J 51:1701592

Monique W, An T, Krassimir B, Prue T (2015) Strategies to reduce tin and other metals in electronic cigarette aerosol. PLoS ONE 10(9):e0138933. https://doi.org/10.1371/journal.pone.0138933 (PMID: 26406602)

Munzel T, Hahad O, Kuntic M, Keaney JF, Deanfield JE, Daiber A (2020) Effects of tobacco cigarettes, e-cigarettes, and waterpipe smoking on endothelial function and clinical outcomes. Eur Heart J. Jun 25 [Epub ahead of print]. https://doi.org/10.1093/ eurheartj/ehaa460

National Academies of Sciences (2018) Engineering, and Medicine. Public health consequences of e-cigarettes. National Academies Press, Washington, DC https://doi.org/10.17226/24952

Naudia G, Mary H, Nathalie G-J, Liza V-B, Clifford W, Steven PR (2019) Analysis of toxic metals in liquid from electronic cigarettes. Int J Environ Res Public Health 16:4450. https://doi.org/ 10.3390/ijerph16224450

Nicholas I, Goldenson AM, Leventhal KA, Simpson JL, Barrington $\mathrm{T}$ ( 2019) A review of the use and appeal of flavored electronic cigarettes. Current Addiction Reports

Nicolas B, Sébastien A, Mélissa S, Nicolas G, Nathalie G, Michael H, Emilie MH, Marc F, Brice MRA, Jean-François G, Delphine A, Guillaume G, Jean-Marc Lo-G, Anne G (2017) Chemical evaluation of electronic cigarettes: multicomponent analysis of liquid refills and their corresponding aerosols, July J Anal Toxicol 41(8):1-9. Follow journal. https://doi.org/10.1093/jat/bkx054. Project: Evaluation of e-cigarette toxicity

Olmedo P, Goessler W, Tanda S, Grau-Perez M, Jarmul S, Aherrera A (2018) Metal concentrations in e-cigarette liquid and aerosol samples: the contribution of metallic coils. Environ Health Perspect 126(2):027010. https://doi.org/10.1289/EHP2175 (PMID: 29467105)

Ontario Agency for Health Protection and Promotion (Public Health Ontario) (2020a) Tobacco and COVID-19 — what we know so far [Internet]. Queen's Printer for Ontario, Toronto, ON [cited 2020 Sep 30]. https://www.publichealthontario.ca/-/media/documents/ ncov/covid-wwksf/2020/08/what-we-know-tobacco-covid.pdf? la $=$ en

Ontario Agency for Health Protection and Promotion (Public Health Ontario) (2020b) Review of "It is time to address airborne transmission of COVID-19" [Internet]. Queen's Printer for Ontario, Toronto, ON [cited 2020 Sep 30]. https://www.publichealthont ario.ca/-/media/documents/ncov/research/2020/07/researchmorawska-clininfectdis-its-time-to-address-airborne-transmissi on.pdf?la=en 
Palazzolo DL, Crow AP, Nelson JM, Johnson RA (2017) Trace metals derived from electronic cigarette (ECIG) generated aerosol: potential problem of ECIG devices that contain nickel. Front Physiol 7:663. https://doi.org/10.3389/fphys.2016.00663 (PMID: 28119618)

Papaefstathiou E, Stylianou M, Agapiou A (2019) Main and side stream effects of electronic cigarettes. J Environ Manag 238:10 17 ([CrossRef])

Pasquale A, Alberto R, Maurizio M (2019) The inorganic fraction in e-liquids used in vapor products including e-cigarettes. J Radioanal Nucl Chem 322:6

Electronic Atomization Cigarette Patent, Link: http://worldwide.espac enet.com/publicationDetails/biblio; jsessionid $=64236 \mathrm{~A} 395 \mathrm{~F}$ 6EE3A8500DBA1E1F82975E.espacenet_levelx_prod_2?FT= D\&date $=20071122 \& \mathrm{DB}=\&$ locale $=$ en_EP $\& C C=\mathrm{US} \& \mathrm{NR}=$ 2007.267031A1\&KC=A1. Accessed 10 Aug 2011

Pearson JL, Hitchman SC, Brose LS, Bauld L, Glasser AM, Villanti AC, McNeill A, Abrams DB, Cohen JE (2018) Recommended core items to assess e-cigarette use in population-based surveys. Tob Control 27(3):341-346

Prokopowicz A, Sobczak A, Szula-Chraplewska M, Ochota P, Kosmider L (2019) Exposure to cadmium and lead in cigarette smokers who switched to electronic cigarettes. Nicotine Tob Res 21:1198-1205 ([CrossRef])

Pushalkar S, Paul B, Li Q, Yang J, Vasconcelos R, Makwana S (2020) Electronic cigarette aerosol modulates the oral microbiome and increases risk of infection. iScience 23(3):100884. https://doi. org/10.1016/j.isci.2020.100884

Raaschou-Nielsen O, Andersen ZJ, Beelen R, Samoli E, Stafoggia M, Weinmayr G (2013) Air pollution and lung cancer incidence in European cohorts: prospective analyses from the European Study of Cohorts for Air Pollution Effects (ESCAPE). Lancet Oncol 14(9):813-822

Russo P, Bonassi S, Giacconi R (2020) COVID-19 and smoking: Is nicotine the hidden link? Eur Respir J 55:2001116

Saffari A, Daher N, Ruprecht A, DeMarco C, Pozzi P, Boffi R (2014) Particulate metals and organic compounds from electronic and tobacco-containing cigarettes: comparison of emission rates and second-hand exposure. Environ Sci Process Impacts 16(10):2259-2267. https://doi.org/10.1039/c4em00415a

Schober W, Szendrei K, Matzen W, Osiander-Fuchs H, Heitmann D, Schettgen T, Jörres RA, Fromme H (2013) Use of electronic cigarettes (e-cigarettes) impairs indoor air quality and increases FeNO levels of e-cigarette consumers. Int J Hyg Environ Health 2014 217:628-637. https://doi.org/10.1016/j.ijheh.11.003

Shane S-C, Monique W, Hua My, Li J, Steve MB, Andrew NR, Timothy WL, Maciej LG, Prue T (2020) Correlation between biomarkers of exposure, effect and potential harm in the urine of electronic cigarette users Sakamaki-Ching S, et al. BMJ Open Respir Res 7:e000452. https://doi.org/10.1136/bmjresp-2019-000452

Shintaro O (2018) Development and validation of an ICP-MS method for simultaneous determination of selected metals in electronic cigarette aeroso, Beiträge zur Tabakforschung International/Contributions to Tobacco Research Volume 28 @ No.1 @ April 2018. https://doi.org/10.2478/cttr--0002

Sohal SS, Eapen MS, Naidu VGM (2019) IQOS exposure impairs human airway cell homeostasis: direct comparison with traditional cigarette and e-cigarette. ERJ Open Res 5:00159-02018

Song JJ, Go YY, Mun JY, Lee S, Im GJ, Kim YY (2018) Effect of electronic cigarettes on human middle ear. Int J Pediatr Otorhinolaryngol 109:67-71. https://doi.org/10.1016/j.ijporl.2018.03. 028 (PMID: 29728187)

Steven PR, Mark RF, Naudia M, Clifford W (2014) Toxic metal concentrations in mainstream smoke from cigarettes available in the USA. Febr J Anal Toxicol 38(4):204-211. https://doi.org/ 10.1093/jat/bku013
Steven RP, Naudia G, Mary H, Liza V-B, Clifford W (2020) Toxic metal-containing particles in aerosols from pod-type electronic cigarettes. J Anal Toxicol 1-11. https://doi.org/10.1093/jat/ bkaa088

Stone EA, Snyder DC, Sheesley RJ, Sullivan AP, Weber RJ, Schauer JJ (2008) Atmos Chem Phys 8:1249-1259

Susi AK, Kharisma AR, Abdillah A (2020) Trend of electronic cigarette use among students in Indonesia. Int J Pharm Res Apr-Jun Vol 12 Issue 3

Talio MC, Alesso M, Acosta M, Wills VS, Fernández LP (2017) Sequential determination of nickel and cadmium in tobacco, molasses and refill solutions for e-cigarettes samples by molecular fluorescence. Talanta 174:221-227

Tayyarah R, Long GA (2014) Comparison of select analytes in aerosol from e-cigarettes with smoke from conventional cigarettes and with ambient air. Regul Toxicol Pharmacol 70(3):704710. https://doi.org/10.1016/j.yrtph.2014.10.010 (PMID: 25444997)

Vinit M, Ki-Hyun K, Pallabi S, Sandeep K, Aggarwal M, Chacko KM (2017) Review on metallic components released due to the use of electronic cigarettes. Environ Eng Res 22(2):131-140. https:// doi.org/10.4491/eer.2017.056

Werner AK, Koumans EH, Chatham-Stephens K (2020) Hospitalizations and deaths associated with EVALI. N Engl J Med 382:1589-1598

Williams M, Talbot P (2019) Design features in multiple generations of electronic cigarette atomizers. IJERPH 16(16):2904. https:// doi.org/10.3390/ijerph16162904

Williams M, Villarreal A, Bozhilov K, Lin S, Talbot P (2013) Metal and silicate particles including nanoparticles are present in electronic cigarette cartomizer fluid and aerosol. PLoS ONE 8(3):e57987. https://doi.org/10.1371/journal.pone.0057987 (PMID: 23526962)

Williams M, Bozhilov K, Ghai S, Talbot P (2017) Elements including metals in the atomizer and aerosol of disposable electronic cigarettes and electronic hookahs. PLoS ONE 12(4):e0175430. https://doi.org/10.1371/journal.pone.0175430 (PMID: 28414730)

Williams M, Bozhilov KN, Talbot P (2019a) Analysis of the elements and metals in multiple generations of electronic cigarette atomizers. Environ Res 175:156-166. https://doi.org/10.1016/j.envres. 2019.05.014 (PMID: 31128425)

Williams M, Li J, Talbot P (2019b) Effects of model, method of collection, and topography on chemical elements and metals in the aerosol of tank-style electronic cigarettes. Sci Rep 9(1):13969. https://doi.org/10.1038/s41598019-50441-4

World Health Organization. (2020) Tobacco Users may be at an increased risk of \#COVID19, both in contracting the disease and complications. https://twitter.com/WHO_Europe/status/12572 55102634745857. Accessed 10 May 2020

Wrapp D, Wang N, Corbett KS (2020) Cryo-EM structure of the 2019-nCoV spike in the prefusion conformation. Science 367:1260-1263

Zervas E, Litsiou E, Glynos K, Chita E, Kalomenidis I, Zakynthinos S (2014) Particle emission of e-cigarette. European Respiratory Society Annual Congress, Munich, Germany. European Respiratory Journal 43

Zhang Y, Sumner W, Chen DR (2013) In vitro particle size distributions in electronic and conventional cigarette aerosols suggest comparable deposition patterns. Nicotine Tob Res 15(2):501-508

Zhao J, Nelson J, Dada O, Pyrgiotakis G, Kavouras IG, Demokritou P (2018) Assessing electronic cigarette emissions: linking physicochemical properties to product brand, e-liquid flavoring additives, operational voltage and user puffing patterns. Inhal Toxicol 30(2):78-88. https://doi.org/10.1080/08958378.2018.1450462 (PMID: 29564955) 
Zhao D, Navas-Acien A, Ilievski V, Slavkovich V, Olmedo P, AdriaMora B (2019) Metal concentrations in electronic cigarette aerosol: effect of open-system and closed-system devices and power settings. Environ Res 174:125-134. https://doi.org/10.1016/j. envres.04.003 (PMID: 31071493)
Publisher's Note Springer Nature remains neutral with regard to jurisdictional claims in published maps and institutional affiliations. 